University of Nebraska - Lincoln

DigitalCommons@University of Nebraska - Lincoln

Publications from USDA-ARS / UNL Faculty

U.S. Department of Agriculture: Agricultural

Research Service, Lincoln, Nebraska

2-27-2008

\title{
Effect of irrigation amounts applied with subsurface drip irrigation on corn evapotranspiration, yield, water use efficiency, and dry matter production in a semiarid climate
}

\author{
Jose O. Payero \\ Queensland Government, Department of Primary Industries and Fisheries, jpayero@clemson.edu \\ David D. Tarkalson \\ USDA-ARS NW Irrigation and Soils Research Lab, david.tarkalson@ars.usda.gov \\ Suat Irmak \\ University of Nebraska-Lincoln, suat.irmak@unl.edu \\ Don Davison \\ University of Nebraska-Lincoln, ddavison1@unl.edu \\ James L. Petersen \\ University of Nebraska-Lincoln, jpetersen2@unl.edu
}

Follow this and additional works at: https://digitalcommons.unl.edu/usdaarsfacpub

Part of the Agricultural Science Commons

Payero, Jose O.; Tarkalson, David D.; Irmak, Suat; Davison, Don; and Petersen, James L., "Effect of irrigation amounts applied with subsurface drip irrigation on corn evapotranspiration, yield, water use efficiency, and dry matter production in a semiarid climate" (2008). Publications from USDA-ARS / UNL Faculty. 199.

https://digitalcommons.unl.edu/usdaarsfacpub/199

This Article is brought to you for free and open access by the U.S. Department of Agriculture: Agricultural Research Service, Lincoln, Nebraska at DigitalCommons@University of Nebraska - Lincoln. It has been accepted for inclusion in Publications from USDA-ARS / UNL Faculty by an authorized administrator of DigitalCommons@University of Nebraska - Lincoln. 


\title{
Effect of irrigation amounts applied with subsurface drip irrigation on corn evapotranspiration, yield, water use efficiency, and dry matter production in a semiarid climate
}

\author{
José O. Payero ${ }^{a, *}$, David D. Tarkalson ${ }^{b}$, Suat Irmak ${ }^{c}$, Don Davison ${ }^{d}$, James L. Petersen ${ }^{d}$ \\ ${ }^{a}$ Queensland Government, Department of Primary Industries and Fisheries (QDPI\&F), 203 Tor Street, Toowoomba, \\ Queensland 4350, Australia \\ ${ }^{\mathrm{b}}$ USDA-ARS NW Irrigation and Soils Research Lab, 3793 North 3600 East, Kimberly, ID 83341, USA \\ ${ }^{\mathrm{c}}$ Department of Biological Systems Engineering, University of Nebraska-Lincoln, 241 L.W. Chase Hall, Lincoln, NE 68583-0726, USA \\ ${ }^{\mathrm{d}}$ University of Nebraska-Lincoln, West Central Research and Extension Center, 461 West University Drive, North Platte, NE 69101, USA
}

\section{A R T I C L E I N F O}

\section{Article history:}

Received 20 July 2007

Accepted 27 February 2008

Keywords:

Subsurface drip irrigation (SDI)

Corn

Maize

Deficit irrigation

Water stress

Water use efficiency

Evapotranspiration (ET)

Harvest index

Dry matter

Yield response factor (ky)

\begin{abstract}
A B S T R A C T
Quantifying the local crop response to irrigation is important for establishing adequate irrigation management strategies. This study evaluated the effect of irrigation applied with subsurface drip irrigation on field corn (Zea mays L.) evapotranspiration (ETc), yield, water use efficiencies (WUE = yield/ETc, and IWUE = yield/irrigation), and dry matter production in the semiarid climate of west central Nebraska. Eight treatments were imposed with irrigation amounts ranging from 53 to $356 \mathrm{~mm}$ in 2005 and from 22 to $226 \mathrm{~mm}$ in 2006 . A soil water balance approach (based on FAO-56) was used to estimate daily soil water and ETc. Treatments resulted in seasonal ETc of 580-663 $\mathrm{mm}$ and $466-656 \mathrm{~mm}$ in 2005 and 2006, respectively. Yields among treatments differed by as much as $22 \%$ in 2005 and $52 \%$ in 2006 . In both seasons, irrigation significantly affected yields, which increased with irrigation up to a point where irrigation became excessive. Distinct relationships were obtained each season. Yields increased linearly with seasonal ETC $\left(R^{2}=0.89\right)$ and ETC/ETp $\left(R^{2}=0.87\right)$ $(\mathrm{ETp}=\mathrm{ETC}$ with no water stress). The yield response factor $(\mathrm{ky})$, which indicates the relative reduction in yield to relative reduction in ETc, averaged 1.58 over the two seasons. WUE increased non-linearly with seasonal ETc and with yield. WUE was more sensitive to irrigation during the drier 2006 season, compared with 2005. Both seasons, IWUE decreased sharply with irrigation. Irrigation significantly affected dry matter production and partitioning into the different plant components (grain, cob, and stover). On average, the grain accounted for the majority of the above-ground plant dry mass $(\approx 59 \%)$, followed by the stover $(\approx 33 \%)$ and the cob $(\approx 8 \%)$. The dry mass of the plant and that of each plant component tended to increase with seasonal ETc. The good relationships obtained in the study between crop performance indicators and seasonal ETc demonstrate that accurate estimates of ETC on a daily and seasonal basis can be valuable for making tactical in-season irrigation management decisions and for strategic irrigation planning and management.
\end{abstract}

Published by Elsevier B.V.

* Corresponding author. Tel.: +61 74688 1513; fax: +61 746881197.

E-mail addresses: jose.payero@dpi.qld.gov.au, jpayero2@hotmail.com (J.O. Payero). 0378-3774/\$ - see front matter. Published by Elsevier B.V.

doi:10.1016/j.agwat.2008.02.015 


\section{Introduction}

Irrigation water supplies are decreasing in many areas of the US Great Plains due to extended drought periods, decline in groundwater levels, litigation among states related to surface water allocations, and diversion of water from irrigation to environmental and municipal uses (McGuire, 2004; McGuire and Fischer, 1999; Lingle and Franti, 1998). Water shortages have heightened the importance of water in agricultural production in the area and have triggered recent regulations affecting irrigation water use. Such regulations include installation of water meters on pumping stations, moratoriums on drilling new wells, and limitations in groundwater pumping to fixed multi-year water allocations. Under these conditions, it is important to know how much yield can be expected from a given water allocation for each alternative crop, which is especially important for field corn (Zea mays L.), the most important irrigated crop in the region.

In the semiarid environment of west central Nebraska, water allocations that result in crop water stress can have a significant impact on corn growth, development, and yield. Knowing how much yield can be expected from a given water allocation, however, is complicated by the fact that corn yield is affected not only by the amount of seasonal irrigation, but also by irrigation timing. Also, yield is affected by other sources of water available to the crop in addition to irrigation. These sources include water stored in the soil profile at crop emergence and effective rainfall occurring during the growing season. Many researchers have shown how corn grain yield can be affected by irrigation timing (Jurgens et al., 1978; NeSmith and Ritchie, 1992; Bryant et al., 1992; Jama and Ottman, 1993). Most of these studies show that corn yield is most affected by water stress when it occurs during the reproductive stages (tasselling, silking, pollination, or grain filling). In Nebraska, the reproductive growth stages coincide with the period of peak crop evapotranspitation (ETc) requirement, making stress during these stages even more significant.

Other studies have linked yields reduction to a reduction in ETc or transpiration, and some researchers have developed different yield versus ETc relationships for different growth stages (Jensen, 1968; Hanks, 1974; Nairizi and Rydzewski, 1977;
Barrett and Skogerboe, 1978; Doorenbos and Kassam, 1979; Gilley et al., 1980; Schneekloth et al., 1991; Klocke et al., 2004). Payero et al. (2006b), however, showed that the reported yield versus ETc relationships for corn are not consistent and vary with location, which is likely due to differences in rainfall pattern, soil and crop characteristics, management practices, and weather conditions.

In Nebraska, research on irrigation has previously focused on sprinkler and surface systems (Gilley et al., 1980; Schneekloth et al., 1991; Hergert et al., 1993; Klocke et al., 2004; Payero et al., 2005, 2006a,b; Schneekloth et al., 2006). However, due to the current and expected limited water supplies, interest in subsurface drip irrigation (SDI) systems to irrigate row crops in Nebraska is growing. Although studies with SDI-irrigated corn have been conducted in other states (Ayars et al., 1999; Camp, 1998; Caldwell et al., 1994; Howell et al., 1997; Lamm et al., 1995; Lamm and Trooien, 2003), local information on the response of corn growth, yield and other crop-water dynamics with SDI is very limited. The agronomic response of the crop to irrigation with SDI is needed to be able to evaluate the economic and technical feasibility of using SDI under local conditions and provide scientifically based practical information to the users on best management practices for SDI-irrigated corn. The objective of this study was to evaluate how different seasonal irrigation depths applied with SDI affected the soil water balance, seasonal evapotranspiration, yield, water use efficiency, and dry matter production of corn in the semiarid climate of west central Nebraska.

\section{Materials and methods}

\subsection{Site description}

Field experiments were conducted during the 2005 and 2006 growing seasons. The experiments were located at the University of Nebraska-Lincoln West Central Research and Extension Center, in North Platte, Nebraska $\left(41.1^{\circ} \mathrm{N}: 100.8^{\circ} \mathrm{W}\right.$ : $861 \mathrm{~m}$ above sea level). The climate at North Platte is semiarid, with average annual precipitation of approximately $508 \mathrm{~mm}$ and reference evapotranspiration of $1403 \mathrm{~mm}$ (USDA, 1978).

Table 1 - Seasonal total and monthly irrigation depths $(\mathrm{mm})$ applied to each corn irrigation treatment (T1-T8) during the 2005 and 2006 growing seasons at North Platte, Nebraska

\begin{tabular}{|c|c|c|c|c|c|c|c|c|c|}
\hline \multirow[t]{2}{*}{ Year } & \multirow[t]{2}{*}{ Month } & \multicolumn{8}{|c|}{ Treatment } \\
\hline & & T1 & T2 & T3 & T4 & T5 & T6 & T7 & T8 \\
\hline \multirow[t]{4}{*}{2005} & July & 53 & 61 & 87 & 87 & 107 & 104 & 105 & 106 \\
\hline & August & 0 & 15 & 15 & 66 & 114 & 150 & 188 & 225 \\
\hline & September & 0 & 0 & 0 & 0 & 0 & 0 & 13 & 25 \\
\hline & Total & 53 & 76 & 102 & 153 & 221 & 254 & 306 & 356 \\
\hline \multirow[t]{5}{*}{2006} & June & 8 & 4 & 8 & 8 & 8 & 8 & 8 & 8 \\
\hline & July & 13 & 62 & 89 & 121 & 124 & 120 & 123 & 176 \\
\hline & August & 0 & 0 & 0 & 0 & 39 & 46 & 65 & 41 \\
\hline & September & 0 & 0 & 0 & 0 & 13 & 0 & 1 & 0 \\
\hline & Total & 22 & 66 & 97 & 130 & 184 & 173 & 197 & 226 \\
\hline
\end{tabular}


On average, about $80 \%$ of the annual precipitation occurs during the growing season, which extends from late-April to mid-October (USDA, 1978). The soil at the experimental site is a Cozad silt loam (fine-silty, mixed, mesic Fluventic haplustoll). From measurements obtained from the experimental plots during this study, it was estimated that the average water contents at field capacity (FC) and permanent wilting point (PWP) in the crop root zone were approximately 0.35 and $0.09 \mathrm{~m}^{3} \mathrm{~m}^{-3}$, respectively.

\subsection{Experimental design}

The field experiment was conducted using a randomized complete block design with eight irrigation treatments (T1-T8) and four replications. Each treatment received a seasonal irrigation allocation, which ranged from 53 to $356 \mathrm{~mm}$ in 2005 and from 22 to $226 \mathrm{~mm}$ in 2006 (Table 1). The aim was to develop well-defined crop response functions to irrigation, ranging from near dryland to over-irrigated conditions. A dryland treatment was not included because some irrigation water was needed to apply nitrogen fertilizer. Irrigations were scheduled to avoid or minimize water stress and deep percolation. The target was to keep the percent soil water depletion in the crop root zone below $50 \%$ of the total available soil water for as much of the season as possible. Another target was to maintain a soil water depletion of at least $50 \mathrm{~mm}$ to store potential rainfall and avoid deep percolation, which was especially important for treatments receiving and excessive allocation. For treatments with a deficient allocation to meet irrigation requirements for the entire season, the strategy was to minimize stress during the peak ETc period (in July), allowing stress later in the season. Once irrigation started, all treatments were irrigated at the same time until the allocation for a given treatment ran out. Irrigations were usually applied two to three times a week. In 2005, irrigations started in midJuly, since rainfall and stored soil water provided adequate moisture for crop development earlier in the season. In 2006, irrigation started in June due to drier soil conditions compared with 2005.

Each experimental plot was $9 \mathrm{~m} \times 37 \mathrm{~m}$, which accommodated 12 corn rows. The crop was irrigated with a SDI system that was installed just prior to planting in 2005, in a field that was planted to surface-irrigated soybean in 2004. The SDI laterals were spaced at $1.5 \mathrm{~m}$ (every other corn row) and were installed at a depth of $0.4 \mathrm{~m}$ between the two crop rows. Laterals were 12.5-mil thin-wall dripper lines (Dripnet PC 1613 F, Netafim USA, Fresno, CA) with inside diameter of $1.6 \mathrm{~cm}$ and pressure-compensating emitters spaced every $46 \mathrm{~cm}$. The nominal flow of the emitters was $0.98 \mathrm{~L} \mathrm{~h}^{-1}$ (applying $1.5 \mathrm{~mm} \mathrm{~h}^{-1}$ ) at a pressure of $69 \mathrm{kPa}$. Water for the system was pumped from the Ogallala aquifer and was filtered using a 152-mm diameter screen filter with a 150mesh screen (model 8060F-MN, Netafim USA, Fresno, CA). Irrigation to each treatment was controlled from a manifold that had eight branches. Each branch had a flow meter (25.4$\mathrm{mm}$ model 36M251T), equipped with a pulse reed switch (model 36RD, Netafim USA, Fresno, CA). It also had a 19-mm electric/manual control valve (model S390-3-0, Dorot Control Valves Inc., Fresno, CA), a pressure regulator ("Standard" model, $0.22-1.26 \mathrm{~L} \mathrm{~s}^{-1}, 62.1 \mathrm{kPa}$ ) (Netafim USA, Fresno, CA), and an air and vacuum relief air vent with shrader valve ("Guardian" model, Netafim USA, Fresno, CA). Irrigations were controlled manually in 2005, and an automatic controller (model NMC-64; Netafim USA, Fresno, CA) was used in 2006.

\subsection{Cultural practices}

Corn was planted on May 18 and 11, and matured on September 23 and 20 in 2005 and 2006, respectively. During both seasons, corn with a comparative relative maturity of 112 days (hybrid Kaystar KX-8615Bt) was planted at 0.76-m row spacing and an average seeding rate of 7.6 seeds per $\mathrm{m}^{2}$. Nitrogen $(\mathrm{N})$ was applied with the starter fertilizer and by fertigating through the SDI system during the growing season. The $\mathrm{N}$ application rate was based on soil analysis. All treatments received $11 \mathrm{~kg} \mathrm{Nha}^{-1}$ as $10-34-0$ with the starter fertilizer. Fertigation with urea ammonium nitrate consisted of $108 \mathrm{~kg} \mathrm{~N} \mathrm{ha}^{-1}$ applied on 15 July 2005, and $213 \mathrm{~kg} \mathrm{Nha}^{-1}$ applied on 5 July 2006. In 2005, an estimated $50 \mathrm{~kg} \mathrm{Nha}^{-1}$ was supplied by the previous soybean crop.

A herbicide mixture $\left(93.4 \mathrm{~L} \mathrm{ha}^{-1}\right)$ containing Lumax ${ }^{\circledR}$ $\left(3.51 \mathrm{~L} \mathrm{ha}^{-1}\right), \quad$ Banvel $^{\circledR} \quad\left(0.58 \mathrm{~L} \mathrm{ha}^{-1}\right), \quad$ Atrazine $90 \mathrm{DF}$ $\left(1.12 \mathrm{~kg} \mathrm{ha}^{-1}\right)$ and crop oil (1.42 L per $378 \mathrm{~L}$ of water) was applied when the crop was at the V4 stage. Target weeds were Kochia (Kochia scoparia L.), Common Lambsquaters (Chenopodium album L.), Redroot Pigweed (Amaranthus restroflexus L.), Field Sandbur (Cenchrus longispinus (Hack.) Fern.), Yellow Foxtail (Setaria glauca L.) and Puncturevine (Tribulus terrestris L.). The insecticide Force ${ }^{\circledR} 3 G\left(4.92 \mathrm{~kg} \mathrm{ha}^{-1}\right)$ was applied using a $18-\mathrm{cm}$ T-band in front of the press wheel at planting time. Target insects were the Corn Rootworm Beetle (Diabrotica virgifera LeConte) and the European Corn Borer (Ostrinia nubilalis (Hübner)). These applications prevented negative effects of weeds and insects on corn growth.

\subsection{Yield and dry matter measurements}

The center three rows $(37 \mathrm{~m})$ of each plot were harvested in early November using a plot combine with a three-row corn head. The combine had a Harvest Data System (model HM-400, Juniper Systems Inc. Logan, Utah), which measured the total mass, water content, and "test weight" of the harvested grain. The grain yield per plot was calculated both in a "dry-mass basis" ( $0 \%$ water content) and in a "wet-mass basis" (standard water content of $15.5 \%$ ).

Eight plants from each plot were also hand-harvested to determine dry matter production and its partitioning into the different plant components (grain, stover, and cob). Plants were cut at ground level and the ears were separated from the stover. The stover samples were weighted, chopped using a tractor-operated plant chopper, and a sub-sample was collected from each plot and weighted. The sub-samples were oven-dried at $70^{\circ} \mathrm{C}$ until they reached a constant mass (7 days) and their masses were recorded. The ear samples were placed in a greenhouse to air-dry to a moisture content of approximately $15-16 \%$, and then weighted and shelled by hand. Grain and cob samples were taken, oven-dried at $70{ }^{\circ} \mathrm{C}$ until they reached a constant mass (7 days), and weighted. 
From this information, the average dry mass per plant and the dry mass and percent of total plant dry mass of the grain, cob, and stover were calculated for each plot.

\subsection{Soil water balance and crop evapotranspiration}

Daily soil water balance and crop evapotranspiration (ETc) were estimated with a computer program that was written in Microsoft Visual Basic ${ }^{\circledR}$. The inputs to the program were daily weather data, including rainfall, irrigation date and amounts, initial water content in the soil profile at crop emergence, and crop- and site-specific information such as planting date, maturity date, soil parameters, maximum rooting depth, etc. Similar daily soil water balance models have previously been used by Robinson and Hubbard (1990), Swan et al. (1990), and Bryant et al. (1992). The computer program calculated daily ETC and the water balance in the crop root zone using the procedure described in FAO-56 (Allen et al., 1998). Readers are referred to the original sources for additional details. This procedure obtains ETC as the product of the evapotranspiration of a grassreference crop $\left(E T_{0}\right)$ and a crop coefficient $\left(K_{c}\right)$. ETo is calculated using the weather data as input to the Penman-Monteith equation and the $K_{\mathrm{c}}$ is used to adjust the estimated $\mathrm{ET}_{\mathrm{o}}$ for the reference crop to that of other crops at different growth stages and growing environments. In this study, the dual $K_{c}$ approach was used, which separates the two components of ETc, namely evaporation (E) and transpiration (T). For corn, this procedure linearly reduces ETC when the soil water depletion in the crop root zone exceeds 55\% (taken from Table 22 in FAO-56) of total available water. Reducing the ETc rate when the crop is under water stress is consistent with the findings of Dwyer and Stewart (1984, 1985), and Gavloski et al. (1992). The dual $K_{c}$ procedure also accounts for the sharp increases in $\mathrm{E}$ due to a wet soil surface following rain or irrigation events. This procedure, therefore, permitted calculation of daily ETc under water-limiting conditions, and when soil water was not limiting (ETp). From the seasonal ETC and ETp values, the ETC/ETp ratio was calculated for each treatment.

Weather data were obtained from an automatic weather station located within $1.5 \mathrm{~km}$ from the research site. This weather station was part of the High Plains Regional Climate Center (HPRCC) weather network. Daily weather data were downloaded from the HPRCC web site (http:// www.hprcc.unl.edu/home.html), including daily maximum and minimum air temperature, relative humidity, wind speed, rainfall, solar radiation, reference and crop ET for different crops, including corn. Rainfall data were also collected manually from rain gauges installed at each of the four corners of the field.

The performance of the computer model was evaluated by comparing its soil water content outputs with values measured using the neutron probe method (Evett and Steiner, 1995). Measurements were made at $0.3-\mathrm{m}$ increments to a depth of $1.8 \mathrm{~m}$ three times each season on 7 July, 15 August, and 23 September 2005, and on 14 June, 11 August, and 21 November 2006. Gravimetric samples were also taken on 7 June 2005 to a depth of $1.0 \mathrm{~m}$.

\subsection{Water use efficiencies}

Water use efficiency (WUE, $\mathrm{kg} \mathrm{m}^{-3}$ ) and irrigation water use efficiency (IWUE, $\mathrm{kg} \mathrm{m}^{-3}$ ) were calculated as

WUE $=\frac{Y}{\mathrm{ETC}}$
IWUE $=\frac{Y}{I}$

where $\mathrm{Y}=$ yield $\left(\mathrm{g} \mathrm{m}^{-2}\right)$, ETc $=$ seasonal crop evapotranspiration $(\mathrm{mm}), \mathrm{I}=$ seasonal irrigation $(\mathrm{mm})$.

\subsection{Statistical analyses}

Analysis of variance (ANOVA) and separation of means were conducted using the GenStat ${ }^{\mathbb{R}}$ for Windows ${ }^{\circledR}$ statistical software (VSN International Ltd., Hertfordshire, UK). To evaluate the effect of irrigation treatment, a separate ANOVA was conducted for each year of the experiment. Year was not included as a factor in the ANOVA since irrigation amounts for the different treatments varied with season. Regression analyses were performed with Microsoft Excel ${ }^{\mathbb{R}}$. The root mean square error (RMSE) was used to evaluate the performance of the soil water balance model. The RMSE was calculated as

$\mathrm{RMSE}=\sqrt{\frac{1}{n} \sum_{i=1}^{n}\left(\mathrm{SW}_{\mathrm{m}}-\mathrm{SW}_{\mathrm{e}}\right)^{2}}$

where $n=$ number of observations, $\mathrm{SW}_{\mathrm{m}}=$ measured soil water $\left(\mathrm{m}^{3} \mathrm{~m}^{-3}\right)$, and $\mathrm{SW}_{\mathrm{e}}=$ estimated soil water $\left(\mathrm{m}^{3} \mathrm{~m}^{-3}\right)$. Because it is an indication of both bias and variance of the $\mathrm{SW}_{\mathrm{e}}$ values with respect to the $\mathrm{SW}_{\mathrm{m}}$ values, the RMSE provides an effective measure to evaluate the performance of the model. Lower RMSE values indicate better agreement between $\mathrm{SW}_{\mathrm{e}}$ and $\mathrm{SW}_{\mathrm{m}}$ values.

\section{Results and discussion}

\subsection{Weather conditions during the growing seasons}

Average values of weather variables during the 2005 and 2006 corn growing seasons at North Platte, Nebraska, are shown in Table 2. The seasonal average air temperature was the same $\left(21.8^{\circ} \mathrm{C}\right)$ during both seasons. In 2006, however, temperatures were hotter in May-July, and cooler in August and September, compared with 2005. On average, wind speed and relative humidity were higher in 2005 . The average solar radiation, however, was about 5\% higher in 2006.

The cumulative daily rainfall during 2005, 2006 and 19822006 at North Platte are shown in Fig. 1. The two seasons had similar annual rainfalls of 409 and $403 \mathrm{~mm}$ for 2005 and 2006, respectively. The rainfall during both seasons was just below the 1982-2006 average of $423 \mathrm{~mm}$. The average rainfall during the last 25 years (1982-2006) was only 83\% of the long-term average of $508 \mathrm{~mm}$ reported in USDA (1978). Although both 
Table 2 - Average weather conditions during the 2005 and 2006 corn growing seasons at North Platte, Nebraska

\begin{tabular}{|c|c|c|c|c|c|c|c|c|}
\hline Year & Month & $\mathrm{T}_{\max }\left({ }^{\circ} \mathrm{C}\right)$ & $\mathrm{T}_{\min }\left({ }^{\circ} \mathrm{C}\right)$ & $\mathrm{T}_{\text {avg }}\left({ }^{\circ} \mathrm{C}\right)$ & $u_{2}\left(\mathrm{~m} \mathrm{~s}^{-1}\right)$ & $\operatorname{Rs}\left(\mathrm{MJ} \mathrm{m}^{-2} \mathrm{~d}^{-1}\right)$ & RH (\%) & VPD $(\mathrm{kPa})$ \\
\hline \multirow[t]{6}{*}{2005} & May & 21.4 & 7.9 & 14.6 & 2.8 & 17.9 & 65.7 & 0.7 \\
\hline & June & 27.6 & 14.2 & 20.9 & 3.2 & 22.5 & 69.5 & 0.9 \\
\hline & July & 32.9 & 16.2 & 24.5 & 3.2 & 24.4 & 57.0 & 1.5 \\
\hline & August & 29.8 & 15.2 & 22.5 & 2.5 & 19.8 & 68.3 & 1.0 \\
\hline & September & 29.4 & 12.9 & 21.2 & 3.2 & 18.4 & 59.5 & 1.2 \\
\hline & Total & 29.4 & 14.3 & 21.8 & 3.0 & 21.2 & 63.9 & 1.1 \\
\hline \multirow[t]{7}{*}{2006} & May & 30.1 & 10.8 & 20.4 & 2.7 & 27.1 & 42.4 & 1.7 \\
\hline & June & 30.5 & 14.7 & 22.6 & 2.8 & 25.7 & 54.5 & 1.5 \\
\hline & July & 32.6 & 17.6 & 25.1 & 2.6 & 24.2 & 58.1 & 1.6 \\
\hline & August & 29.2 & 15.6 & 22.4 & 2.6 & 18.3 & 68.9 & 1.0 \\
\hline & September & 23.6 & 7.2 & 15.4 & 2.2 & 17.0 & 68.5 & 0.7 \\
\hline & Total & 29.6 & 14.0 & 21.8 & 2.6 & 22.4 & 59.5 & 1.3 \\
\hline & Grand total & 29.5 & 14.1 & 21.8 & 2.8 & 21.8 & 61.7 & 1.2 \\
\hline
\end{tabular}

$T_{\max }=$ maximum air temperature, $T_{\min }=$ minimum air temperature, $T_{\text {avg }}=$ average air temperature, $u_{2}=$ wind speed at $2 \mathrm{~m}$ height, Rs $=$ solar radiation, $\mathrm{RH}=$ relative humidity, $\mathrm{VPD}$ = vapour pressure deficit, only data from corn emergence to maturity were included.

seasons had similar rainfall, 2005 followed a wetter-thannormal year (2004), while 2006 followed a year with justbelow-normal rainfall. Therefore, there was a higher chance of having more water stored in the soil profile at planting in 2005 compared with 2006.

The monthly distribution of rainfall for 2005, 2006, and the 1982-2006 average for rainfall and alfalfa-reference evapotranspiration (ETr) at North Platte are shown in Fig. 2. ETr values, instead of $\mathrm{ET}_{\mathrm{o}}$, are normally reported by the HPRCC and are used here. However, ETc values in this study were calculated based on $\mathrm{ET}_{\mathrm{O}}$. At North Platte, ETr is normally much higher than rainfall, which explains the need for irrigation. The average annual rainfall for 1982-2006 was $423 \mathrm{~mm}$, while ETr was $1532 \mathrm{~mm}$, therefore, rainfall represented only $27.6 \%$ of ETr.

During 2005 and 2006 there was almost twice as much rain in June, which is the wettest month for the area, compared with the long-term average. The total in-season rain was very similar both seasons, with 295 and $282 \mathrm{~mm}$ for 2005 and 2006, respectively. However, in 2005 there was considerably more rain in May, making more water available to the crop at planting

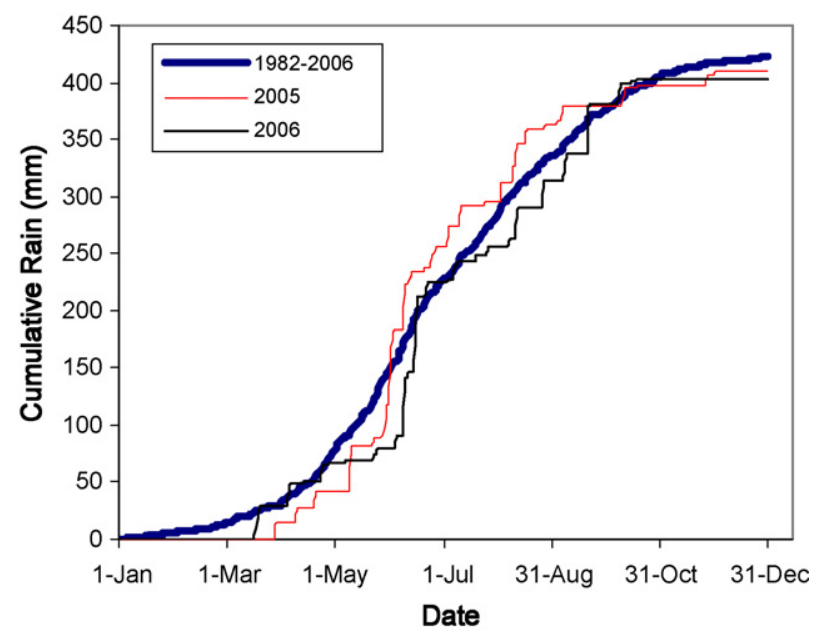

Fig. 1 - Cumulative rain for 2005, 2006 and 1982-2006 at North Platte, Nebraska. time and early in the season compared with 2006. In 2006, there was very little rain in May (only $13 \mathrm{~mm}$ ), which was well below normal. In 2006, there was more rain in September than in 2005. That additional rain in September, however, occurred too late in the growing season to have a significant impact on crop growth and yield, considering that by 1 September 2006 the corn had already entered the R5 growth stage (dent) (Hoeft et al., 2000). During both seasons, rain in July was considerably below normal. This is significant because July had the peak ETr (Fig. 2), and the corn had progressed to the reproductive growth stages. The R1 growth stage (silking) started on 18 July and 11 July in 2005 and 2006, respectively.

\subsection{Initial soil water}

In 2005, all treatments started with the same soil water profile, since there was abundant rain in May and irrigation treatments were not applied in the experimental plots in 2004 . Gravimetric soil sampling in early June (Fig. 3) showed a near uniform soil water content in the top $1 \mathrm{~m}$ of soil profile, although later measurements showed considerable water depletion deeper in the soil profile. In 2006, however, due to little rain in May and to the irrigation treatments applied in 2005, there were considerable differences in the initial soil water profiles among treatments (Fig. 3). The treatments that were deficit irrigated in 2005 started the 2006 season with little soil water, especially deep in the profile.

\subsection{Performance of the soil water balance model}

The computer model provided very good estimates of average soil water in the crop root zone compared with neutron probe measurements during both seasons (Fig. 4). On average, the estimated soil water values tended to follow the 1:1 line when compared with measured values during both seasons. Also the measured and estimated values were linearly related with high $R^{2}$ values of 0.90 and 0.85 in 2005 and 2006, respectively. The RMSEs calculated between the estimated and measured values were also relatively small with 0.018 and $0.019 \mathrm{~m}^{3} \mathrm{~m}^{-3}$ for 2005 and 2006, respectively. 


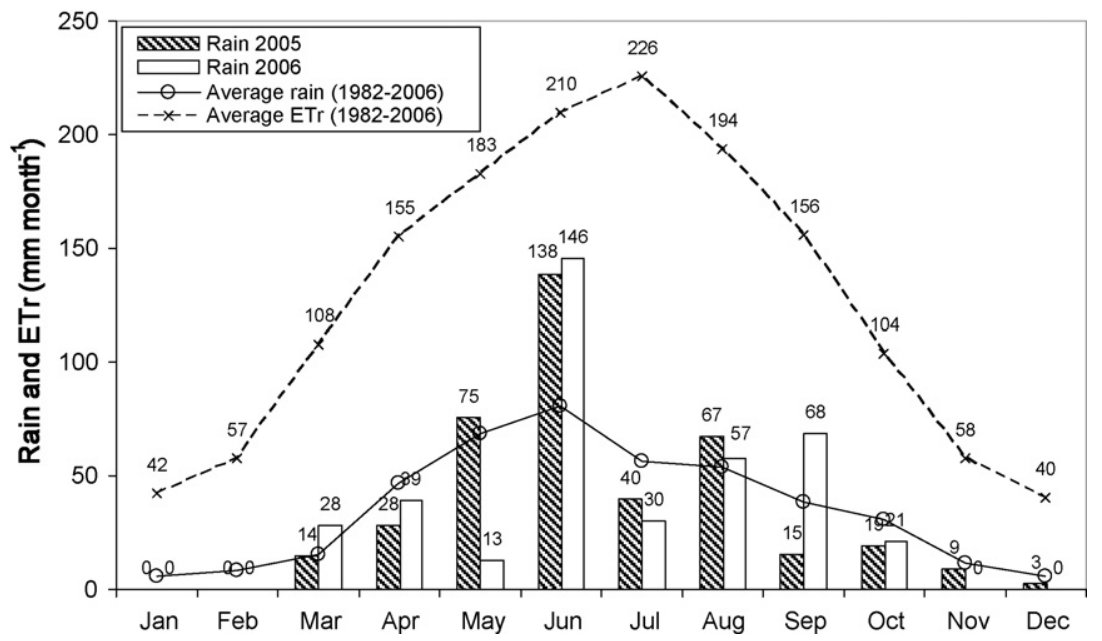

Fig. 2 - Monthly rain for 2005, 2006, and the long-term averages (1982-2006) for rain and alfalfa-reference evapotranspiration (ETr) at North Platte, Nebraska.
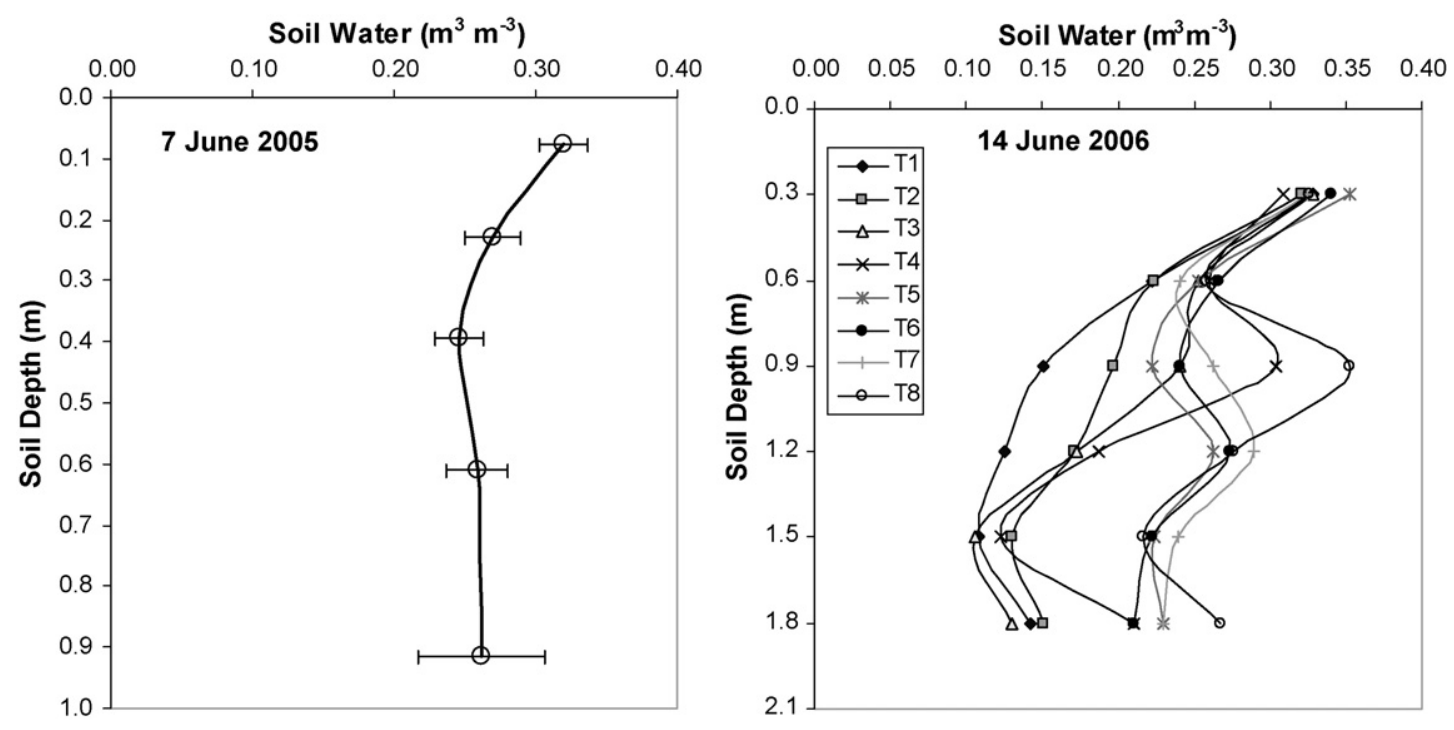

Fig. 3 - Average soil water for all treatments measured from gravimetric samples in June 2005 (error bars are treatment means \pm standard deviation), and soil water for the different irrigation treatments (T1-T8) measured with the neutron probe method in June 2006.

\subsection{Effect of irrigation on evapotranspiration}

The potential corn evapotranspiration (ETp) $(\mathrm{ETp}=\mathrm{ETC}$ with no water stress) from emergence to the R6 growth stage (physiological maturity or "black-layer") was practically the same during both seasons, calculated at $663 \mathrm{~mm}$. The cumulative ETp was linearly related (except early in the season) to the Fraction of Season ${ }^{1}$ (Fs) (Fig. 5). Both seasons, cumulative ETp followed the same straight line after approximately Fs $\geq 0.25$ in 2005 and Fs $\geq 0.20$ in 2006. Where properly calibrated, this linear relationship between cumulative ETp and Fs can potentially be used to extrapolate and predict ETp

\footnotetext{
${ }^{1}$ Fraction of Season is the ratio of cumulative growing degree days (CGDD) from crop emergence to required CGDD from crop emergence to maturity.
}

during the season and to make in-crop irrigation scheduling decisions. Payero et al. (2005) reported similar linear relationships for soybean at this site.

During both seasons, ETc increased with irrigation up to a point where irrigation became excessive (Fig. 6). No increase in ETc was observed for irrigation amounts above $221 \mathrm{~mm}$ (T5) in 2005 and $173 \mathrm{~mm}$ (T6) in 2006. There was a steeper increase in ETc with irrigation during 2006 compared with 2005.

The cumulative crop evapotranspiration (ETC) for each treatment and the cumulative ETp are shown in Fig. 7. During both seasons, some of the treatments suffered from water stress, although water supplies were adequate for all treatments early in the season. In 2005, stress for the driest treatment started in mid August. In 2006, however, stress for the driest treatment occurred about a month earlier (in mid July). Stress created differences in seasonal ETc among 

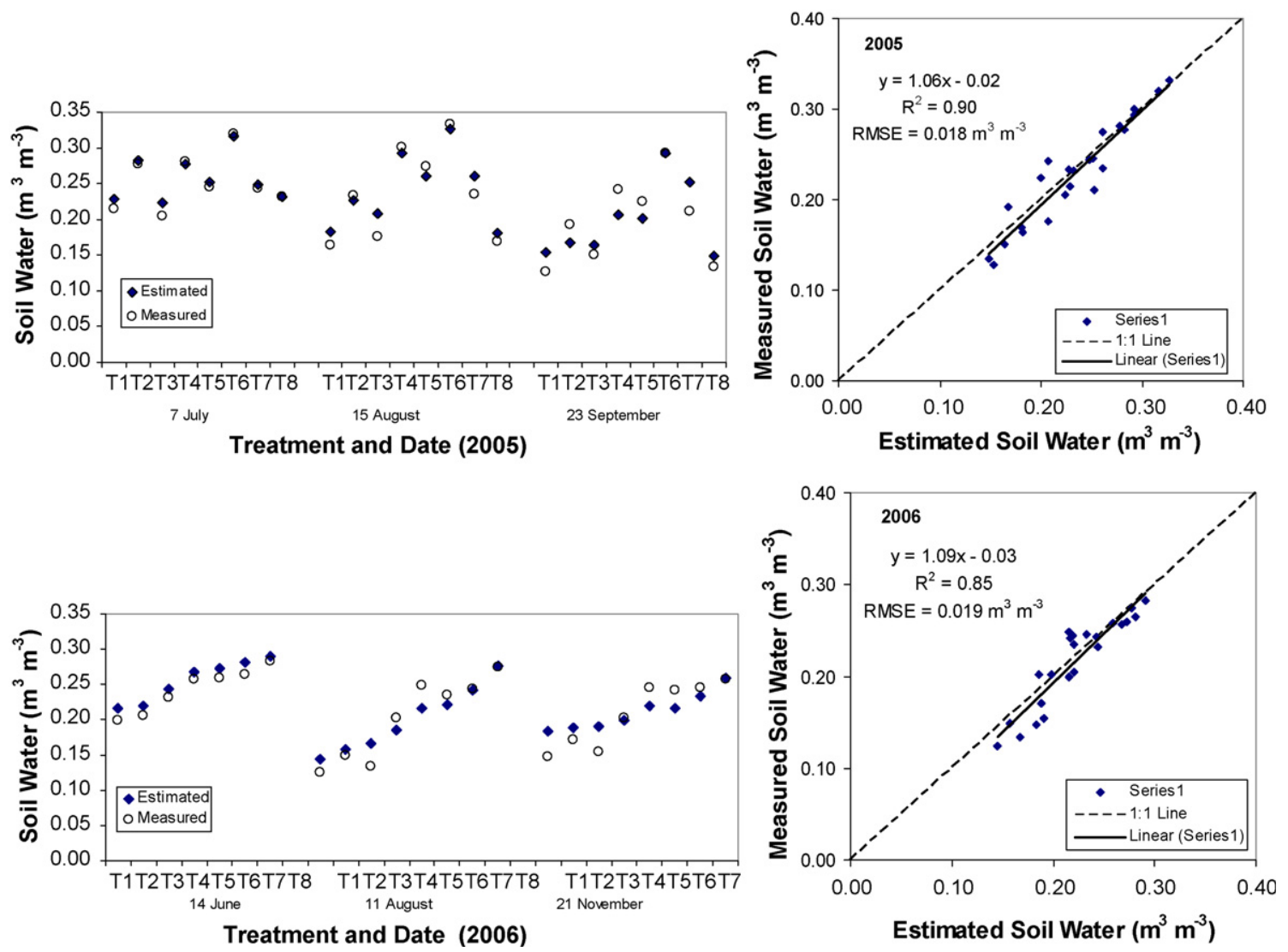

Fig. 4 - Estimated and measured soil water content obtained at North Platte, Nebraska, during the 2005 and 2006 growing seasons. Each data point represents the average soil water content in the crop root zone to a depth of $1.8 \mathrm{~m}$ for each treatment (T1-T8), including three sampling dates each year. RMSE is the root mean squared error.

treatments. A wider range of seasonal ETc among treatments resulted in 2006 compared with 2005. The seasonal ETc and ETc/ETp ratios for the different treatments are shown in Table 3. In 2005, seasonal ETc for all treatments averaged

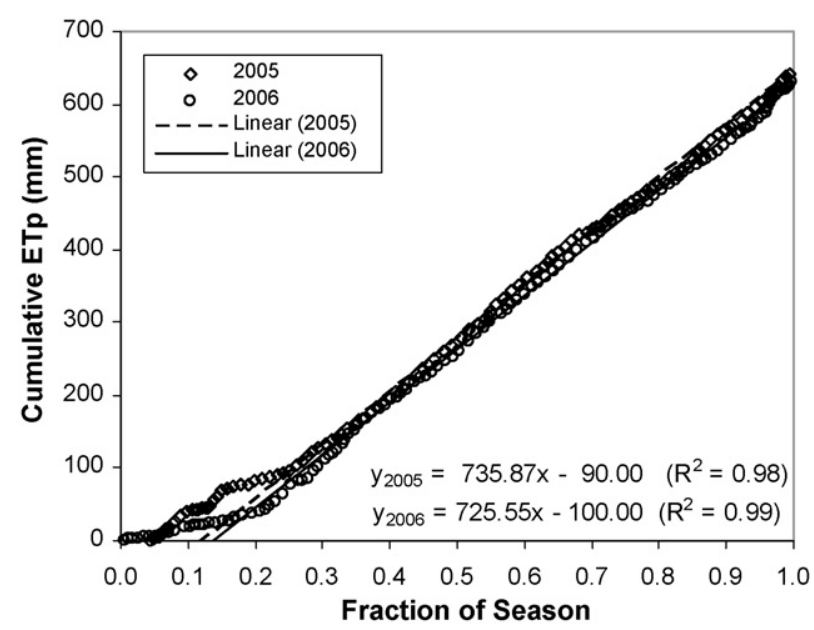

Fig. 5 - Relationships between cumulative ETp and Fraction of season (FS) obtained during the 2005 and 2006 growing seasons at North Platte, NE. ETp = crop evapotranspiration (ETc) with no water stress. FS is the ratio of cumulative growing degree days (CGDD) from crop emergence to required CGDD from crop emergence to maturity.
$630 \mathrm{~mm}$ and ranged from 580-663 $\mathrm{mm}$. The ETc/ETp ratio averaged 0.95 and ranged from 0.87 to 1.00. In 2006, drier soil conditions resulted in a lower seasonal ETc that averaged $600 \mathrm{~mm}$ and ranged from 466 to $656 \mathrm{~mm}$. The ETc/ETp ratio averaged 0.90 and ranged from 0.70 to 0.99 .

\subsection{Effect of irrigation on yield and water use efficiencies}

Yield, water use efficiency (WUE), and irrigation water use efficiency (IWUE) for the different treatments are shown in Table 4, both in "dry-mass basis" and "wet-mass basis". Irrigation significantly affected yields during both years. Yields were higher in 2005 compared with 2006, averaging, in a "dry-mass basis," 968 and $828 \mathrm{~g} \mathrm{~m}^{-2}$ in 2005 and 2006, respectively. In 2005, yields ranged from 844 to $1085 \mathrm{~g} \mathrm{~m}^{-2}$, a yield difference of $241 \mathrm{~g} \mathrm{~m}^{-2}(22 \%)$. In 2006 , yields ranged from 455 to $957 \mathrm{~g} \mathrm{~m}^{-2}$, a yield difference of $502 \mathrm{~g} \mathrm{~m}^{-2}$ (52\%).

Relationships relating yield to seasonal irrigation, ETc, ETc/ ETp are shown in Fig. 8A-C. It also shows the relative yield decrease with respect to the relative evapotranspiration deficit (Fig. 8D) as proposed by Doorenbos and Kassam (1979). During both seasons, yields tended to increase with irrigation up to the point where irrigation became excessive (Fig. 8A). Although not quantified, excessive irrigation most likely reduced the amount of oxygen in the crop root zone and increased the likelihood of nitrogen leaching, making less of it available for crop uptake. During both seasons yields peaked 


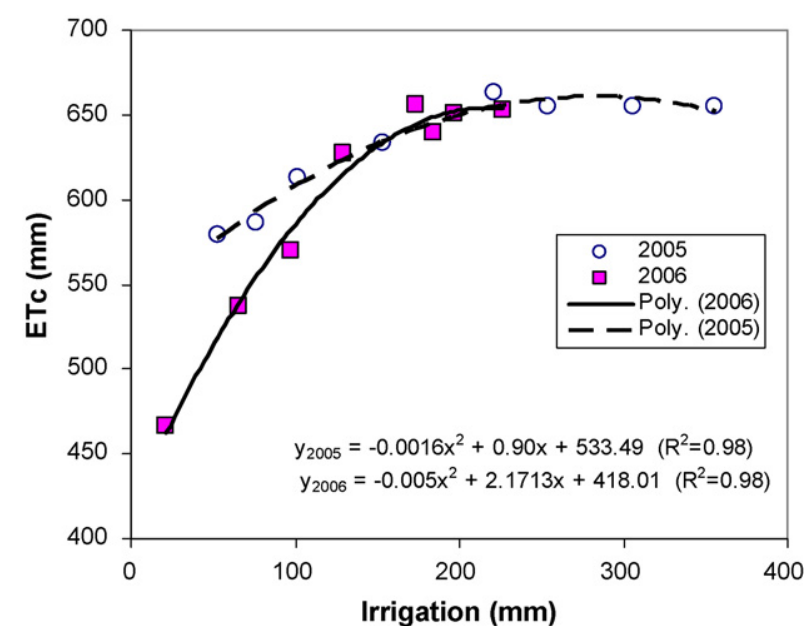

Fig. 6 - Relationship between irrigation and seasonal crop evapotranspiration (ETc) for corn obtained at North Platte, Nebraska, during 2005 and 2006.

with treatment T6, which applied 254 and $173 \mathrm{~mm}$ of irrigation in 2005 and 2006, respectively. Different yield versus irrigation functions were obtained each season, with a steeper slope obtained in 2006. When seasonal irrigation was not excessive,

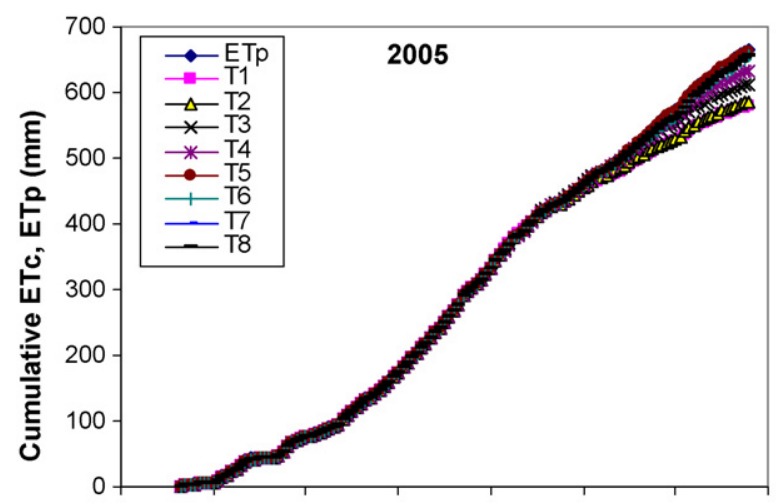

10-May 30-May 19-Jun 9-Jul 29-Jul 18-Aug 7-Sep 27-Sep Date

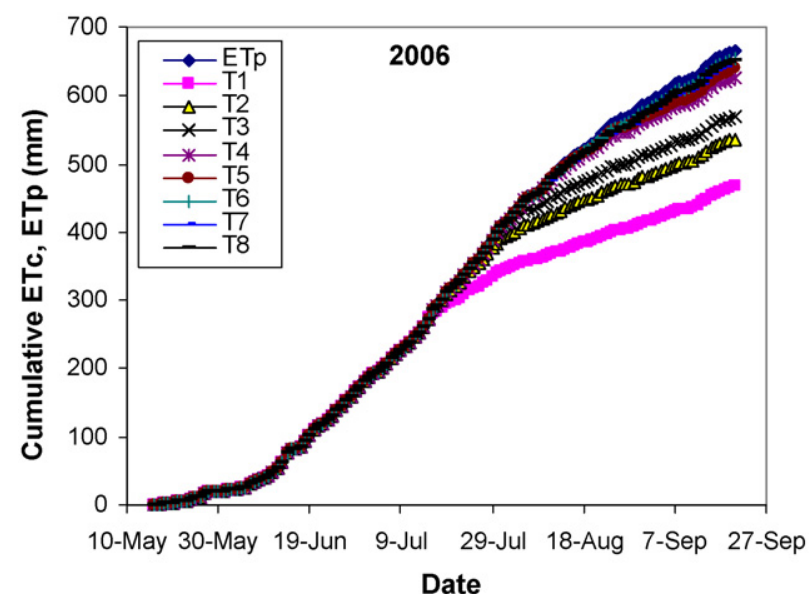

Fig. 7 - Cumulative corn evapotranspiration (ETc) for each irrigation treatment (T1-T8) during the 2005 and 2006 growing seasons at North Platte, Nebraska. ETp = ETc with no water stress.
Table 3 - Seasonal corn evapotranspiration calculated for each irrigation treatment during the 2005 and 2006 growing seasons at North Platte, Nebraska

\begin{tabular}{lccccc} 
Treatment & \multicolumn{2}{c}{$2005(\mathrm{ETp}=663 \mathrm{~mm})$} & & \multicolumn{2}{c}{$2006(\mathrm{ETp}=663 \mathrm{~mm})$} \\
\cline { 2 - 3 } \cline { 6 - 6 } & ETc $(\mathrm{mm})$ & ETc/ETp & & ETc $(\mathrm{mm})$ & ETc/ETp \\
\hline T1 & 580 & 0.87 & & 466 & 0.70 \\
$\mathrm{~T} 2$ & 586 & 0.88 & & 537 & 0.81 \\
$\mathrm{~T} 3$ & 612 & 0.92 & & 570 & 0.86 \\
$\mathrm{~T} 4$ & 633 & 0.96 & & 627 & 0.95 \\
$\mathrm{~T} 5$ & 663 & 1.00 & & 639 & 0.96 \\
T6 & 655 & 0.99 & & 656 & 0.99 \\
T7 & 655 & 0.99 & & 651 & 0.98 \\
T8 & 655 & 0.99 & & 653 & 0.99 \\
Average & 630 & 0.95 & & 600 & 0.90 \\
Minimum & 580 & 0.87 & & 466 & 0.70 \\
Maximum & 663 & 1.00 & & 656 & 0.99 \\
\hline
\end{tabular}

ETC $=$ crop evapotranspiration and ETp $=$ ETc with no water stress

higher yields were obtained with the same amount of irrigation in 2005 compared with 2006. These results are not surprising since the relationship between yield and irrigation is not unique and varies with season and location. On the other hand, yields were linearly related to seasonal ETC (Fig. 8B) and to seasonal ETC/ETp (Fig. 8C), and the relationships practically followed the same line during both seasons.

Good linear relationships between relative evapotranspiration deficit and relative yield decrease were observed in 2006 and combining data from the two seasons (2005-2006) (Fig. 8D). In 2005 the relation was poor probably due to the limited stress observed that year. The slope of the line in Fig. 8D represents the yield response factors (ky) as proposed by Doorenbos and Kassam (1979). The ky= 1.58 was higher than the 1.25 value reported by Doorenbos and Kassam (1979) for stress during the total growing period, but close to the 1.50 value reported for stress during the reproductive stages.

WUE values varied considerably with irrigation treatment, especially during the drier 2006 season (Table 4). Values tended to be higher in 2005, averaging 1.53 and $1.37 \mathrm{~kg} \mathrm{~m}^{-3}$ (dry-mass basis) in 2005 and 2006, respectively. Differences in WUE between the driest and wettest treatment were 12 and $35 \%$ in 2005 and 2006, respectively. Irrigation treatments, however, impacted IWUE much more than WUE. Differences in IWUE between the driest and wettest treatment were 82 and $80 \%$ in 2005 and 2006, respectively. Fig. 9 shows that WUE increased non-linearly with seasonal ETc and with yield, when combining data from both seasons. Both of these relationships are determined by the observed linear relationship between yield and ETc (Fig. 8B). If the relationship between yield and ETC is linear (yield $=$ slope $\times$ ETC - intercept), then for $\mathrm{WUE}=0, \mathrm{ETC}=$ (intercept/slope), and yield $=0$. The curvilinear function results from the fact that the intercept $\neq 0$.

Fig. 10 shows IWUE and WUE as functions of irrigation. IWUE sharply decreased with irrigation, with similar tendencies observed during both seasons. The decreasing tendency of IWUI with irrigation is expected in areas where the dryland yield (yield with no irrigation) is positive. However, in situations when no dryland yield can be obtained without irrigation, IWUE would be expected to increase with irrigation, and in situations when the dryland yield is exactly zero (a rare 
Table 4 - Corn yield, water use efficiency (WUE), and irrigation water use efficiency (IWUE) for each irrigation treatment obtained in 2005 and 2006 at North Platte, Nebraska, considering grain yield in both dry-mass and wet-mass basis

\begin{tabular}{|c|c|c|c|c|c|c|c|c|c|c|c|c|}
\hline \multirow[t]{3}{*}{ Treat } & \multicolumn{6}{|c|}{ Dry-mass basis } & \multicolumn{6}{|c|}{ Wet-mass basis } \\
\hline & \multicolumn{3}{|c|}{2005} & \multicolumn{3}{|c|}{2006} & \multicolumn{3}{|c|}{2005} & \multicolumn{3}{|c|}{2006} \\
\hline & $\begin{array}{c}\text { Yield } \\
\left(\mathrm{g} \mathrm{m}^{-2}\right)\end{array}$ & $\begin{array}{c}\text { IWUE } \\
\left(\mathrm{kg} \mathrm{m}^{-3}\right)\end{array}$ & $\begin{array}{c}\text { WUE } \\
\left(\mathrm{kg} \mathrm{m}^{-3}\right)\end{array}$ & $\begin{array}{c}\text { Yield } \\
\left(\mathrm{g} \mathrm{m}^{-2}\right)\end{array}$ & $\begin{array}{c}\text { IWUE } \\
\left(\mathrm{kg} \mathrm{m}^{-3}\right)\end{array}$ & $\begin{array}{c}\text { WUE } \\
\left(\mathrm{kg} \mathrm{m}^{-3}\right)\end{array}$ & $\begin{array}{c}\text { Yield } \\
\left(\mathrm{g} \mathrm{m}^{-2}\right)\end{array}$ & $\begin{array}{c}\text { IWUE } \\
\left(\mathrm{kg} \mathrm{m}^{-3}\right)\end{array}$ & $\begin{array}{c}\text { WUE } \\
\left(\mathrm{kg} \mathrm{m}^{-3}\right)\end{array}$ & $\begin{array}{c}\text { Yield } \\
\left(\mathrm{g} \mathrm{m}^{-2}\right)\end{array}$ & $\begin{array}{c}\text { IWUE } \\
\left(\mathrm{kg} \mathrm{m}^{-3}\right)\end{array}$ & $\begin{array}{c}\text { WUE } \\
\left(\mathrm{kg} \mathrm{m}^{-3}\right)\end{array}$ \\
\hline $\mathrm{T} 1$ & $844 \mathrm{e}$ & 15.93 & 1.46 & $455 \mathrm{e}$ & 21.08 & 0.98 & 999 e & 18.85 & 1.72 & 539 e & 24.95 & 1.16 \\
\hline T2 & $901 \mathrm{de}$ & 11.85 & 1.54 & $711 \mathrm{~d}$ & 10.77 & 1.32 & $1066 \mathrm{de}$ & 14.03 & 1.82 & $842 \mathrm{~d}$ & 12.74 & 1.57 \\
\hline T3 & $932 \mathrm{~cd}$ & 9.14 & 1.52 & $814 \mathrm{c}$ & 8.37 & 1.43 & $1103 \mathrm{~cd}$ & 10.81 & 1.80 & $963 c$ & 9.90 & 1.69 \\
\hline $\mathrm{T} 4$ & $935 \mathrm{~cd}$ & 6.11 & 1.48 & $875 \mathrm{cb}$ & 6.76 & 1.40 & $1106 \mathrm{~cd}$ & 7.23 & 1.75 & $1036 \mathrm{cb}$ & 8.00 & 1.65 \\
\hline T5 & $1022 a b$ & 4.62 & 1.54 & 953 a & 5.17 & 1.49 & $1209 \mathrm{ab}$ & 5.47 & 1.82 & $1128 \mathrm{a}$ & 6.12 & 1.76 \\
\hline T6 & $1085 \mathrm{a}$ & 4.27 & 1.66 & 957 a & 5.52 & 1.46 & $1284 \mathrm{a}$ & 5.06 & 1.96 & $1133 \mathrm{a}$ & 6.53 & 1.73 \\
\hline $\mathrm{T} 7$ & 984 bc & 3.21 & 1.50 & $927 a b$ & 4.70 & 1.42 & $1164 \mathrm{bc}$ & 3.80 & 1.78 & $1097 \mathrm{ab}$ & 5.56 & 1.68 \\
\hline T8 & $1040 \mathrm{ab}$ & 2.92 & 1.59 & $933 \mathrm{ab}$ & 4.13 & 1.43 & $1231 \mathrm{ab}$ & 3.46 & 1.88 & $1104 \mathrm{ab}$ & 4.88 & 1.69 \\
\hline Average & 968 & 7.26 & 1.53 & 828 & 8.31 & 1.37 & 1145 & 8.59 & 1.82 & 980 & 9.84 & 1.62 \\
\hline Minimum & 844 & 2.92 & 1.46 & 455 & 4.13 & 0.98 & 999 & 3.46 & 1.72 & 539 & 4.88 & 1.16 \\
\hline Maximum & 1085 & 15.93 & 1.66 & 957 & 21.08 & 1.49 & 1284 & 18.85 & 1.96 & 1133 & 24.95 & 1.76 \\
\hline Difference & 241 & 13.01 & 0.20 & 502 & 16.95 & 0.51 & 285 & 15.39 & 0.24 & 594 & 20.06 & 0.61 \\
\hline Difference (\%) & $22 \%$ & $82 \%$ & $12 \%$ & $52 \%$ & $80 \%$ & $35 \%$ & $22 \%$ & $82 \%$ & $12 \%$ & $52 \%$ & $80 \%$ & $35 \%$ \\
\hline S.E.M. & 26 & & & 29 & & & 26 & & & 29 & & \\
\hline
\end{tabular}

WUE = yield/[seasonal crop evapotranspiration], IWUE = yield/irrigation. The "dry-mass basis" and "wet-mass basis" yields were calculated at 0 and $15.5 \%$ grain water contents, respectively. Yields with the same letters are not significantly different at the $5 \%$ significance level. S.E.M. = standard errors of means.
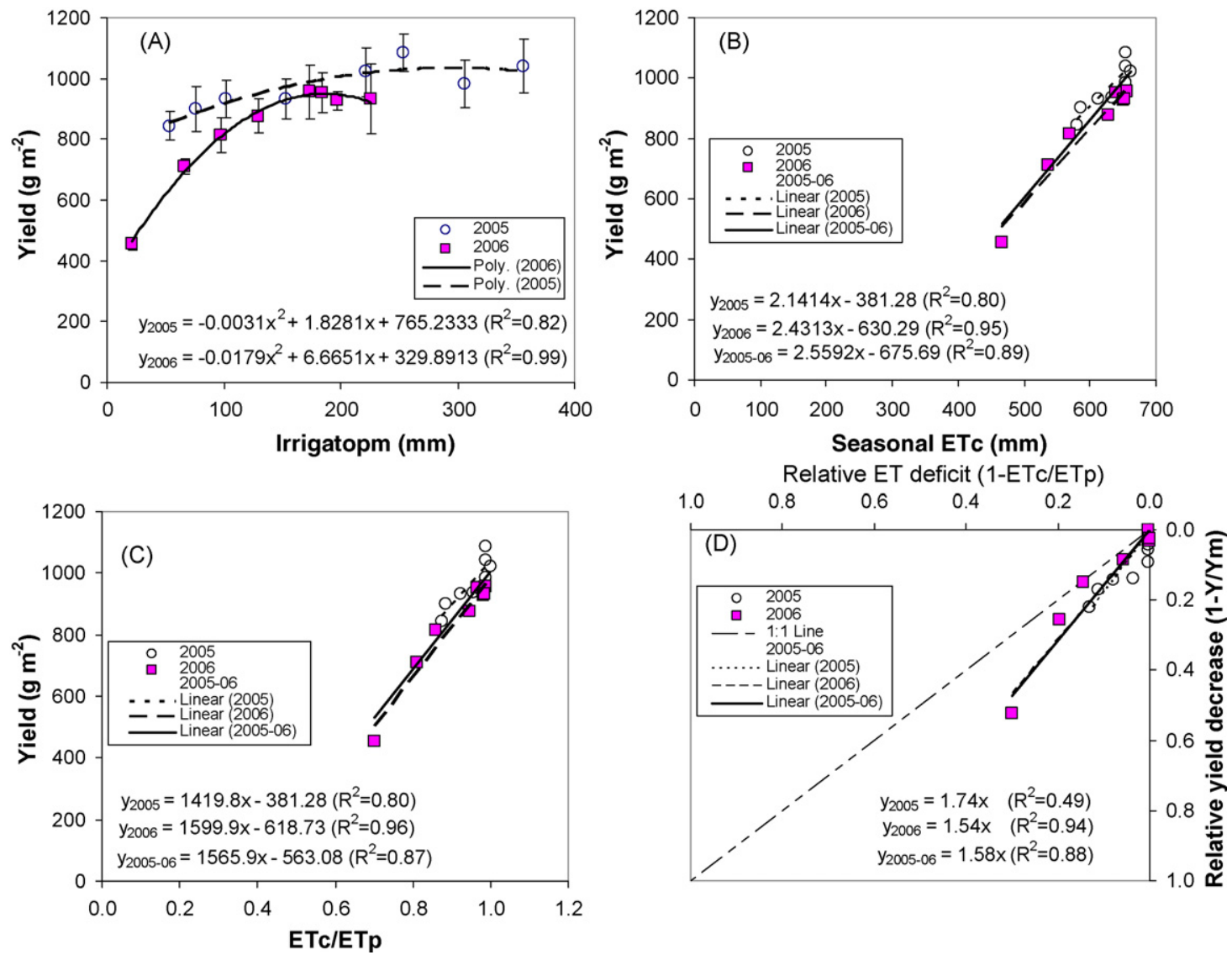

Fig. 8 - Corn yield response to seasonal irrigation, evapotranspiration (ETc) and ETc/ETp obtained during 2005 and 2006 at North Platte, Nebraska. ETp = ETc with not water stress, $Y=$ yield and $Y_{m}=$ maximum yield. Yields were calculated in a drymass basis ( $0 \%$ grain water content). Error bars are treatment means \pm standard deviation. 

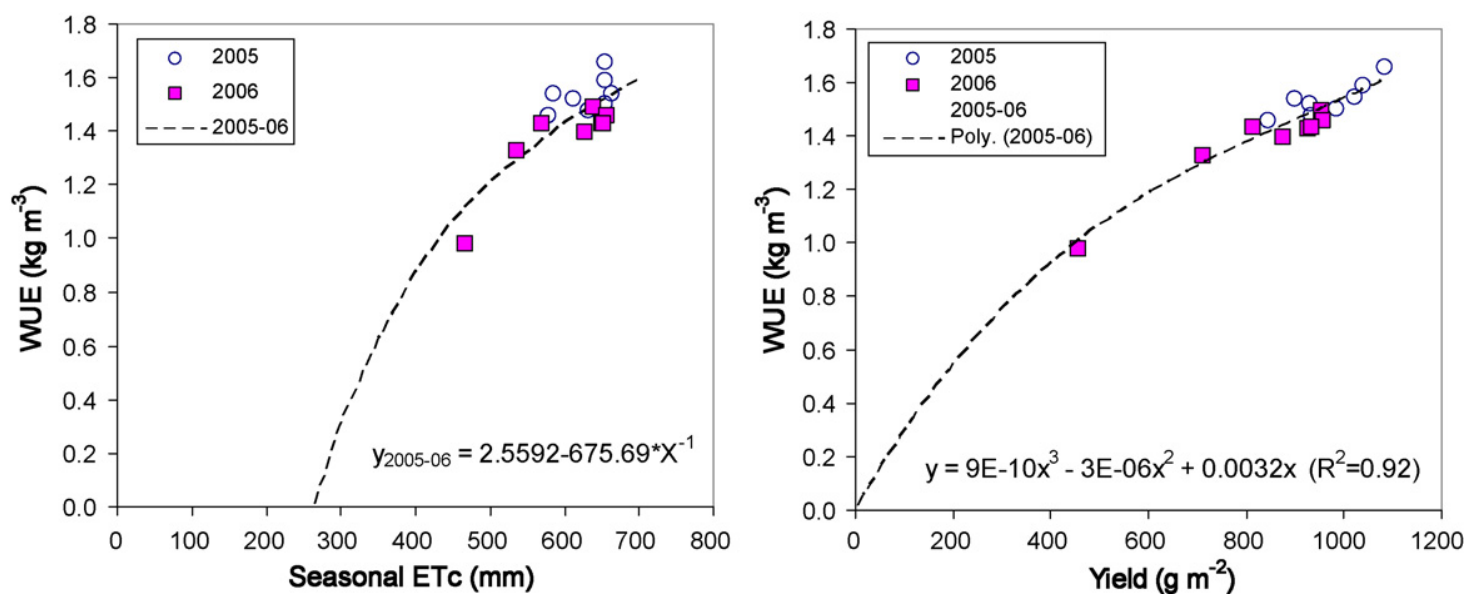

Fig. 9 - Corn water use efficiency (yield/ETC) as a function of seasonal crop evapotranspiration (ETc) and yield obtained during 2005 and 2006 at North Platte, Nebraska. Functions were extrapolated beyond observed values to fit the values dictated by the observed yield versus ETc linear function. Yields were calculated in a dry-mass basis ( $0 \%$ grain water content).
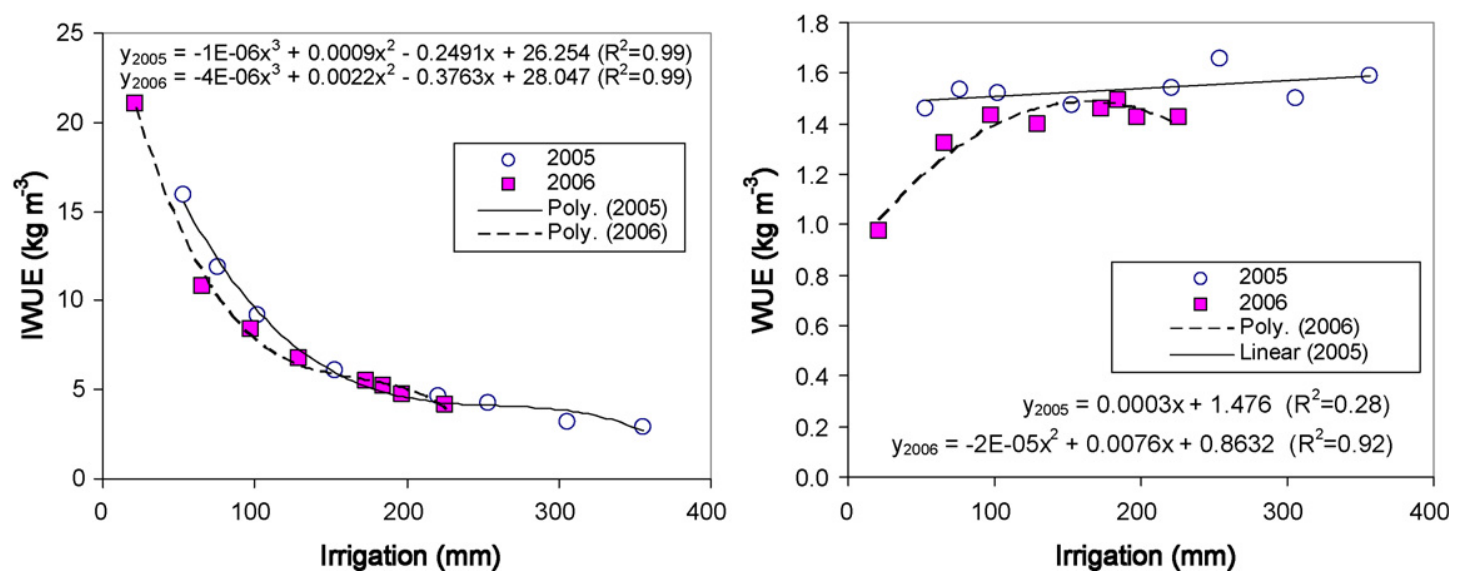

Fig. 10 - Corn water use efficiency (WUE = yield/ETc) and irrigation water use efficiency (IWUE = yield/irrigation) as a function of seasonal irrigation obtained during 2005 and 2006 at North Platte, Nebraska. ETc = crop evapotranspiration. Yields to determine WUE and IWUE were calculated in a dry-mass basis ( $0 \%$ grain water content).

coincidence), IWUE would be constant with irrigation, assuming no over-irrigation. Fig. 10 also shows that WUE varied little with irrigation in 2005 , but tended to be well related to irrigation in 2006. In 2006, WUE increased with irrigation up to the point where additional irrigation did not produce additional yield, in a similar fashion as the relationship between irrigation and yield (Fig. 8A). These results show that IWUE and WUE had an opposite behavior with irrigation.

Some researchers and the general public often refer to "increasing water use efficiency" in general terms as a desirable objective. In some cases they are referring to WUE and in others to IWUE or other measures of water use efficiency such as yield/(total water) (total water = rain + irrigation + soil water). These results show that these terms should not be interchanged and care should be taken to define exactly what it is that they want to increase. The feasibility of increasing either the WUE or IWUE is a decision that needs to be based not only on the biophysical response of the crop but also on economic factors. Often the objective of producers is not to increase yields but to increase profits. If water is the factor limiting production, increasing IWUE (which means decreasing WUE) could be desirable. In instances where water is not the limiting factor, irrigation to produce maximum yield, which will tend to increase WUE but to decrease IWUE could be the most profitable option. Determining the level of irrigation needed to optimize profits can be complex and depends on both biophysical and economic factors (English et al., 2002; Martin et al., 1989; Norton et al., 2000).

\subsection{Effect of irrigation on dry matter production}

The dry matter productions for the entire corn plant and for the different plant components (grain, cob, and stover) obtained during the two seasons are shown in Table 5. Data 
Table 5 - Corn dry matter production obtained during 2005 and 2006 with different irrigation treatments at North Platte, Nebraska

\begin{tabular}{|c|c|c|c|c|c|c|c|}
\hline \multirow[t]{2}{*}{ Year, treatment } & \multicolumn{4}{|c|}{ Dry mass (g plant ${ }^{-1}$ ) } & \multicolumn{3}{|c|}{$\%$ Of plant dry mass } \\
\hline & Plant & Grain & $\mathrm{Cob}$ & Stover & \%Grain & $\% \mathrm{Cob}$ & $\%$ Stover \\
\hline 2005, T1 & 248 bc & $146 \mathrm{bc}$ & $22 \mathrm{a}$ & $80 \mathrm{a}$ & $58.8 \mathrm{ab}$ & $9.0 \mathrm{a}$ & $32.2 \mathrm{~b}$ \\
\hline $\mathrm{T} 2$ & $244 \mathrm{c}$ & $137 \mathrm{c}$ & $21 \mathrm{a}$ & $86 \mathrm{a}$ & $56.2 \mathrm{~d}$ & $8.6 \mathrm{bc}$ & $35.2 \mathrm{a}$ \\
\hline T3 & $258 \mathrm{bc}$ & $149 \mathrm{bc}$ & $22 \mathrm{a}$ & $87 \mathrm{a}$ & $57.6 \mathrm{bcd}$ & $8.6 \mathrm{~b}$ & $33.7 \mathrm{ab}$ \\
\hline $\mathrm{T} 4$ & $264 \mathrm{bc}$ & $155 \mathrm{bc}$ & $23 \mathrm{a}$ & $86 \mathrm{a}$ & $58.7 \mathrm{ab}$ & $8.6 \mathrm{~b}$ & $32.6 \mathrm{~b}$ \\
\hline T5 & $281 a b$ & $163 a b$ & $24 \mathrm{a}$ & $95 \mathrm{a}$ & $57.9 \mathrm{abc}$ & $8.5 b c$ & $33.6 \mathrm{ab}$ \\
\hline T6 & 307 a & $175 \mathrm{a}$ & $26 \mathrm{a}$ & $106 \mathrm{a}$ & $57.0 \mathrm{~cd}$ & $8.4 \mathrm{bc}$ & $34.6 \mathrm{a}$ \\
\hline $\mathrm{T} 7$ & 262 bc & $155 \mathrm{bc}$ & $22 \mathrm{a}$ & $84 \mathrm{a}$ & $59.3 \mathrm{a}$ & $8.6 \mathrm{bc}$ & $32.1 \mathrm{~b}$ \\
\hline T8 & $284 \mathrm{ab}$ & $162 \mathrm{ab}$ & $24 \mathrm{a}$ & $98 \mathrm{a}$ & $57.2 \mathrm{~cd}$ & $8.3 \mathrm{c}$ & $34.4 \mathrm{a}$ \\
\hline Average (2005) & 268.5 & 155.3 & 23.01 & 90.2 & 57.9 & 8.58 & 33.6 \\
\hline 2006, T1 & $143 \mathrm{a}$ & $74 \mathrm{a}$ & $10 \mathrm{a}$ & $59 \mathrm{a}$ & $52.2 \mathrm{a}$ & $6.9 \mathrm{a}$ & $41.0 \mathrm{c}$ \\
\hline T2 & $221 \mathrm{~b}$ & $131 \mathrm{~b}$ & $17 \mathrm{~b}$ & 73 a & $59.4 \mathrm{~b}$ & $7.7 \mathrm{a}$ & $32.9 \mathrm{~b}$ \\
\hline T3 & $240 \mathrm{~b}$ & $147 \mathrm{~b}$ & $19 \mathrm{~b}$ & $74 \mathrm{a}$ & $61.2 \mathrm{bc}$ & $7.8 \mathrm{a}$ & $31.0 \mathrm{ab}$ \\
\hline $\mathrm{T} 4$ & $246 b$ & $152 \mathrm{~b}$ & $19 \mathrm{~b}$ & $75 \mathrm{a}$ & $61.6 \mathrm{c}$ & $7.6 \mathrm{a}$ & 30.8 a \\
\hline T5 & $248 \mathrm{~b}$ & $152 \mathrm{~b}$ & $18 \mathrm{~b}$ & 79 a & $61.0 \mathrm{bc}$ & $7.3 \mathrm{a}$ & $31.8 \mathrm{ab}$ \\
\hline T6 & $247 \mathrm{~b}$ & $152 \mathrm{~b}$ & $18 \mathrm{~b}$ & $76 \mathrm{a}$ & $61.7 \mathrm{c}$ & $7.4 \mathrm{a}$ & 30.9 a \\
\hline $\mathrm{T} 7$ & $254 \mathrm{~b}$ & $157 \mathrm{~b}$ & $19 \mathrm{~b}$ & $78 \mathrm{a}$ & $61.7 \mathrm{c}$ & $7.5 \mathrm{a}$ & 30.7 a \\
\hline $\mathrm{T} 8$ & $262 b$ & $162 b$ & $20 \mathrm{~b}$ & $80 \mathrm{a}$ & $61.8 \mathrm{c}$ & $7.5 \mathrm{a}$ & $30.7 \mathrm{a}$ \\
\hline Average (2006) & 232.7 & 140.8 & 17.5 & 74.4 & 60.1 & 7.5 & 32.5 \\
\hline Average (2005-2006) & 250.6 & 148.1 & 20.2 & 82.3 & 59.0 & 8.0 & 33.0 \\
\hline
\end{tabular}
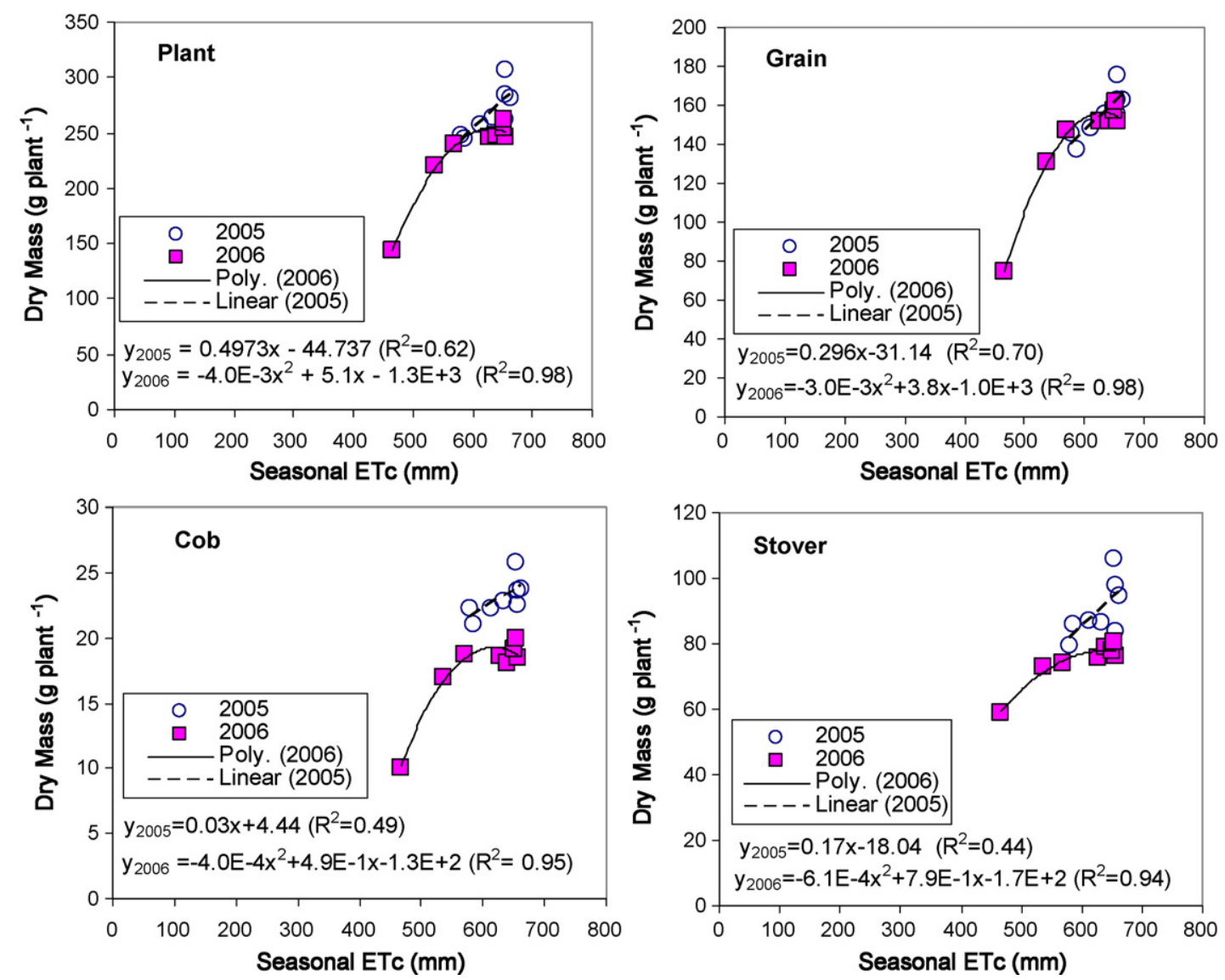

Fig. 11 - Relationships between corn seasonal evapotranspiration (ETC) and the dry mass of the plant, grain, cob, and stover obtained with different irrigation treatments during 2005 and 2006 at North Platte, NE. Differences in dry mass of plant, grain and cob among treatments were statistically significant at the $5 \%$ significance level for both seasons, while those of the stover were not. 

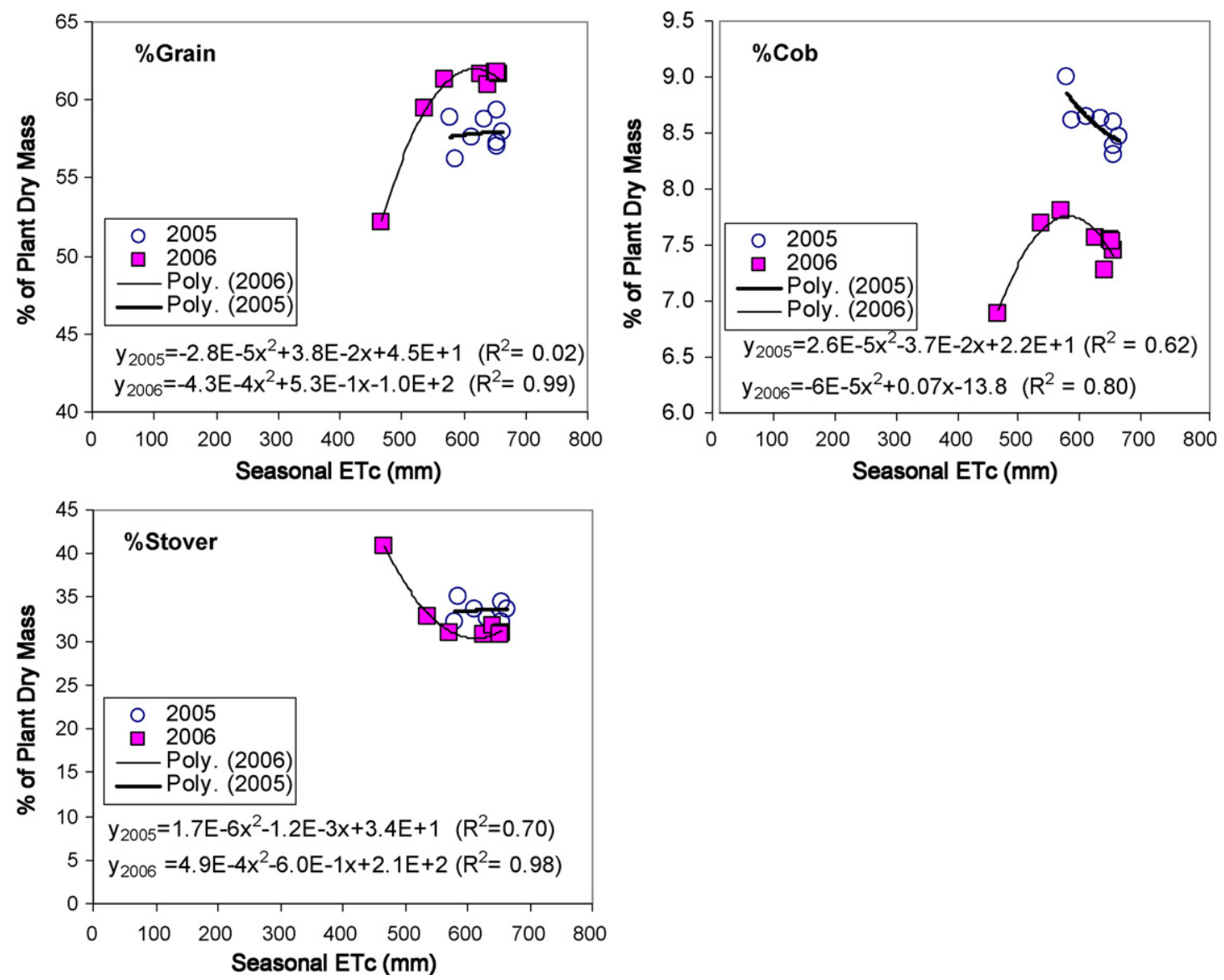

Fig. 12 - Relationships between corn seasonal evapotranspiration (ETc) and the \% of dry mass partitioned into grain (\%Grain), cob (\%Cob) and stover (\%Stover) obtained with different irrigation treatments during 2005 and 2006 at North Platte, NE. Except for \%Cob in 2006, differences among treatments in all variables were statistically significant at the $5 \%$ significance level.

are presented as dry mass per plant and as a percentage of total plant dry mass (\%Grain, \%Cob, and \%Stover). On average for all treatments, dry matter production (dry mass) for the plant and for each of the plant components was higher in 2005 than in 2006. In a percentage basis, however, the \%Grain was higher, while the \%Cob and \%Stover were lower in 2006. In 2005, irrigation treatments significantly affected all dry matter variables, except for the dry mass of the cob and the stover. In 2006, all variables were significantly affected by irrigation treatments, except for the dry mass of the stover and the $\%$ Cob.

Combining data for both seasons, crop yield (dry-mass basis, $\mathrm{g} \mathrm{m}^{-2}$ ) was linearly related to the plant dry mass (g plant $\left.{ }^{-1}\right)\left(R^{2}=0.93\right)$ as

yield $=4.09$ (plant dry mass $)-127.57$

A linear relationship for corn was also reported by Howell et al. (1997). This is not surprising because on average for both seasons, the grain accounted for about $59 \%$ of the plant dry mass, the stover for about 33\%, and the cob for about $8 \%$. The proportion of grain dry mass to total above-ground plant dry mass is usually known as the harvest index (HI), which is a value commonly used in crop modeling (Stockle and
Campbell, 1985; Bryant et al., 1992). Stockle and Campbell (1985) indicated that the HI was a function of crop water stress and estimated it using empirical linear functions of a stress coefficient. Similarly, Bryant et al. (1992) estimated the $\mathrm{HI}$ by multiplying the ETC/ETp ratio by a potential HI values. They assumed a potential HI value for corn of 0.50 (50\%), which was much lower than the values obtained in this study. Traore et al. (2000) found that HI was affected by water stress only when the stress occurred at anthesis. Under nonstress conditions they obtained HI values as high as 0.59 (59\%), which were similar to the values obtained in this study for the fully irrigated treatments. The maximum $\mathrm{HI}$ obtained in this study was approximately 0.62 (61.77\% for treatment $\mathrm{T} 8$ in 2006). For plants stressed at or after tasseling, however, they obtained HI values as low as 0.28 (28\%).

The relationships between corn dry matter production and seasonal ETc, in terms of dry mass and in a percentage basis, are shown in Figs. 11 and 12, respectively. The dry mass of the whole plant and for each of its components increased with seasonal ETc during both seasons, although better relationships were obtained in 2006 due to the wider range in seasonal ETC among treatments. In a percentage basis, \%Grain was poorly related to seasonal ETc in 2005 , but a very good 
relationship was obtained in 2006. In 2006, \%Grain increased with seasonal ETc and then tended to level off for seasonal ETc above about $580 \mathrm{~mm}$. The \%Cob was well related to seasonal ETc during both seasons. In 2005, it decreased with ETc for ETc above about $580 \mathrm{~mm}$. The same tendency was observed in 2006, but \%Cob increased with ETc when ETc was below about $580 \mathrm{~mm}$. The \%Stover was very well related and decreased with seasonal ETc in 2006 for those treatments with seasonal ETc of less than about $580 \mathrm{~mm}$. Since in 2005 all treatments had seasonal ETc of $580 \mathrm{~mm}$ or higher, the \%Stover was relatively constant with seasonal ETc.

\section{Conclusions}

This study evaluated the effect of different seasonal irrigation depths on corn evapotranspiration, yield, water use efficiency, and dry matter production in the semiarid climate of west central Nebraska during 2005 and 2006. During both seasons, some of the irrigation treatments resulted in crop stress, which reduced seasonal ETc. In 2005, seasonal ETc for all treatments averaged $630 \mathrm{~mm}$ and ranged from 580 to $663 \mathrm{~mm}$. In 2006, drier growing conditions resulted in a lower seasonal ETc that averaged $600 \mathrm{~mm}$ and ranged from 466 to $656 \mathrm{~mm}$.

The differences in seasonal ETc among treatments significantly affected crop yields. In 2005, yields (dry-mass basis) averaged $968 \mathrm{~g} \mathrm{~m}^{-2}$ and ranged from 844 to $1085 \mathrm{~g} \mathrm{~m}^{-2}$ (a difference of 22\%). In 2006, yields averaged $828 \mathrm{~g} \mathrm{~m}^{-2}$ and ranged from 455 to $957 \mathrm{~g} \mathrm{~m}^{-2}$ (a difference of 52\%). During both seasons, irrigation significantly affected yields, which increased with irrigation up to the point where irrigation became excessive. Different yield versus irrigation functions were obtained each season, with a steeper slope obtained in 2006. Yields increased linearly with seasonal ETc $\left(R^{2}=0.89\right)$ and ETc/ETp $\left(R^{2}=0.87\right)$, with similar relationships observed both seasons. The average yield response factor (ky) (Doorenbos and Kassam, 1979), which indicates the effect of water stress on reducing crop yield, averaged 1.58 over the 2 years. This value was higher than the 1.25 value reported by Doorenbos and Kassam (1979) for stress during the total growing period, but close to the 1.50 value reported for stress during the reproductive stages.

Combining the data for both seasons, WUE increased nonlinearly with seasonal ETc and with yield. IWUE sharply decreased with increasing irrigation amount, with similar trends observed during both seasons, while WUE tended to increase as irrigation amount increased.

On average for all treatments, the dry mass for the plant and for each of the plant components (grain, cob, and stover) was higher in 2005 than in 2006. In a percentage basis, however, the \%Grain was higher, while the \%Cob and \%Stover were lower in 2006. In 2005, irrigation treatments significantly affected all dry matter variables, except for the dry mass of the cob and the stover. In 2006, all variables were significantly affected by irrigation treatments, except for the dry mass of the stover and the \%Cob. The grain accounted for the majority of the above-ground plant dry mass $(\approx 59 \%)$, followed by the stover $(\approx 33 \%)$ and the cob $(\approx 8 \%)$. The good relationships obtained in the study between seasonal ETc and crop performance indicators (such as yield, WUE, IWUE, and dry matter) demonstrate that accurate estimates of ETc in a daily and seasonal basis can be valuable for making tactical in-crop irrigation management decisions and for long-term and pre-season strategic irrigation planning.

\section{Acknowledgements}

The University of Nebraska Agricultural Research Division, Lincoln, NE 68583, Journal Serial No. 15126. Partial funding for this project was provided by the U.S. Department of the Interior, Bureau of Reclamation. Names of commercial products are solely provided as information to the reader and do not imply an endorsement or recommendation by the authors or their organizations.

\section{REFEREN CES}

Allen, R.G., Pereira, L.S., Raes, D., Smith, M., 1998. Crop evapotranspiration-guidelines for computing crop water requirements (Irrigation and Drainage Paper No. 56). Food and Agriculture Organization of the United Nations (FAO), Rome, Italy.

Ayars, J.E., Phene, C.J., Hutmacher, R.B., Davis, K.R., Schoneman, R.A., Vail, S.S., Mead, R.M., 1999. Subsurface drip irrigation of row crops: a review of 15 years of research at the Water Management Research Laboratory. Agric. Water Manage. 42, 1-27.

Barrett, J.W.H., Skogerboe, G.V., 1978. Effect of irrigation regime on maize yields. J. Irrig. Drain. Div. 104, 179-194.

Bryant, K.J., Benson, V.W., Kiniry, J.R., Williams, J.R., Lacewell, R.D., 1992. Simulating corn yield response to irrigation timings: validation of the Epic model. J. Prod. Agric. 5, 237242.

Caldwell, D.S., Spurgeon, W.E., Manges, H.L., 1994. Frequency of irrigation for subsurface drip-irrigated corn. Trans. ASAE 31 (4), 1099-1103.

Camp, C.R., 1998. Subsurface drip irrigation: a review. Trans. ASAE 41 (5), 1353-1367.

Doorenbos, J., Kassam, A.H., 1979. Yield response to water. FAO Irrigation and Drainage Paper No.33. FAO, Rome, Italy, $193 \mathrm{pp}$.

Dwyer, L.M., Stewart, D.W., 1984. Indicators of water stress in corn (Zea mays L.). Can. J. Plant Sci. 64, 537-546.

Dwyer, L.M., Stewart, D.W., 1985. Water stress conditioning of corn (Zea mays) in the field and the greenhouse. Can. J. Bot. 63, 704-710.

English, M.J., Solomon, K.H., Hoffman, G.J., 2002. A paradigm shift in irrigation management. J. Irrig. Drain. Eng. 128, 267-277.

Evett, S.R., Steiner, J.L., 1995. Precision of neutron scattering and capacitance type soil water content gauges from field calibration. Soil Sci. Soc. Am. J. 59, 961-968.

Gavloski, J.E., Whitfield, G.H., Ellis, C.R., 1992. Effect of restricting watering on sap flow and growth in corn (Zea mays L.). Can. J. Plant Sci. 72, 361-368.

Gilley, J.R., Watts, D.G., Sullivan, C.Y., 1980. Management of Irrigation Agriculture with a Limited Water and Energy Supply. Institute of Agriculture and Natural Resources, University of Nebraska-Lincoln, p. 168.

Hanks, R.J., 1974. Model for predicting plant yield as influenced by water use. Agron. J. 66, 660-664. 
Hergert, G.W., Klocke, N.L., Petersen, J.L., Nordquist, P.T., Clark, R.T., Wicks, G.A., 1993. Cropping systems for stretching limited irrigation supplies. J. Prod. Agric. 6, 520-528.

Hoeft, R.G., Nafziger, E.D., Johnson, R.R., Aldrich, S.R., 2000. Modern Corn and Soybean Production, 1st ed. MCSP Publications, Champaign, IL, USA.

Howell, T.A., Schneider, A.D., Evett, S.R., 1997. Subsurface and surface microirrigation of corn-Southern High Plains. Trans. ASAE 40 (3), 635-641.

Jama, A.O., Ottman, M.J., 1993. Timing of the first irrigation in corn and water stress conditioning. Agron. J. 85, 1159-1164.

Jensen, M.E., 1968. Water consumption by agricultural plants. In: Kozlowski, T.T. (Ed.), Water Deficits and Plant Growth. Academic Press, New York, pp. 1-22.

Jurgens, S.K., Johnson, R.R., Boyer, J.S., 1978. Dry matter production and translocation in maize subjected to drought during grain fill. Agron. J. 70, 678-682.

Klocke, N.L., Schneekloth, J.P., Melvin, S., Clark, R.T., Payero, J.O., 2004. Field scale limited irrigation scenarios for water policy strategies. Appl. Eng. Agric. 20, 623-631.

Lamm, F.R., Trooien, T.P., 2003. Subsurface drip irrigation for corn production: a review of 10 years of research in Kansas. Irrig. Sci. 22, 195-200.

Lamm, F.R., Manges, H.L., Stone, L.R., Khan, A.H., Rogers, D.H., 1995. Water requirement of subsurface drip-irrigated corn in Northwest Kansas. Trans. ASAE 38 (2), 441-448.

Lingle, G.R., Franti, T.G., 1998. What is the "Cooperative Agreement" for endangered species habitat along the Central Platte River? NebFact NF98-375. University of Nebraska-Lincoln Cooperative Extension Publication, 5 pp. Available at http://ianrpubs.unl.edu/wildlife/nf375.htm.

Martin, D.L., Brocklin, J.V., Wilmes, G., 1989. Operating rules for deficit irrigation management. Trans. ASAE 32, 1207-1215.

McGuire, V.L., 2004. Water-level changes in the High Plains Aquifer, predevelopment to 2002, 1980 to 2002, and 2001 to 2002. Fact Sheet 2004-3026. U.S. Geological Survey, Lincoln.

McGuire, V.L., Fischer, B.C., 1999. Water-level changes, 1980 to 1997, and saturated thickness, 1996-1997, in the High Plains Aquifer. Fact Sheet 124-99. U.S. Geological Survey, Lincoln.

Nairizi, S., Rydzewski, J.R., 1977. Effects of dated soil moisture stress on crop yields. Exp. Agric. 13, 51-59.
NeSmith, D.S., Ritchie, J.T., 1992. Short- and long-term responses of corn to pre-anthesis soil water deficit. Agron. J. 84, 107-113.

Norton, N.A., Clark, R.T., Schneekloth, J.P., 2000. Effects of alternative irrigation allocations on water use, net returns, and marginal user costs. In: Western Agricultural Economics Association Annual Meetings, Vancouver, British Columbia, p. 13.

Payero, J.O., Melvin, S.R., Irmak, S., 2005. Response of soybean to deficit irrigation in the semi-arid environment of WestCentral Nebraska. Trans. ASAE 48, 2189-2203.

Payero, J.O., Klocke, N.L., Schneekloth, J.P., Davison, D.R., 2006a. Comparison of irrigation strategies for surface-irrigated corn in West Central Nebraska. Irrig. Sci. 24, 257-265.

Payero, J.O., Melvin, S.R., Irmak, S., Tarkalson, D., 2006b. Yield response of corn to deficit irrigation in a semi-arid climate. Agric. Water Manage. 84, 101-112.

Robinson, J.M., Hubbard, K.G., 1990. Soil water assessment model for several crops in the High Plains. Agron. J. 82, 1141-1148.

Schneekloth, J.P., Klocke, N.L., Hergert, G.W., Martin, D.L., Clark, R.T., 1991. Crop rotations with full and limited irrigation and dryland management. Trans. ASAE 34, 2372-2380.

Schneekloth, J., Klocke, N.L., Davison, D.R., Payero, J.O., 2006. Furrow irrigation management with limited water. Appl. Eng. Agric. 22, 391-398.

Stockle, C., Campbell, G., 1985. A simulation model for predicting effect of water stress on yield: an example using corn. Advances in Irrigation, vol. 3. Academic Press, Inc., pp. 283-311.

Swan, J.B., Staricka, J.A., Shaffer, M.J., Paulson, W.H., Peterson, A.E., 1990. Corn yield response to water stress, heat units, and management: model development and calibration. Soil Sci. Soc. Am. J. 54, 209-216.

Traore, S.B., Carlson, R.E., Pilcher, C.D., Rice, M.E., 2000. Bt and non-Bt maize growth and development as affected by temperature and drought stress. Agron. J. 92, 1027-1035.

USDA, 1978. Soil survey of Lincoln County, Nebraska. A publication of the U.S. Department of Agriculture Soil Conservation Service, in cooperation with the University of Nebraska Conservation and Survey Division. 